\title{
Impact of Human Resources Training on the Performances of Banks-An Empirical Study
}

\author{
Mohammad Rokibul Kabir, Md. Maruf Ullah, Mustafa Manir Chowdhury \\ International Islamic University Chittagong, Chittagong, Bangladesh
}

\begin{abstract}
The study is based on a total number of 23 listed commercial banks operating in Bangladesh. The research is the upshot of both primary and secondary data. Primary data for exploring the relationship between training and productivity of the banks were collected from the bank officials on the basis of a structured questionnaire using direct interview method. Secondary data were collected from the annual reports of the selected banks. The study mainly aimed at finding the relationship between training and productivity as well as to observe the effect of training cost on profitability. The results obtained through Statistical Software SPSS-20 revealed that the productivity growth after training is significant as paired sample $T$-test indicated a significant difference of productivity before and after training at $1 \%$ level. Similarly, the fitted regression model for training cost and profit of banks shows a positive impact of training cost on profitability.
\end{abstract}

Keywords: training, productivity, training cost, profit, banks

\section{Introduction}

Present Scenario of business world is characterized by a growing competitiveness, market globalization and technological advances in organization. The survival of an organization implies the prosecution of sustainable competitive advantages.

Sing and Mohanty (2012) argued that the knowledge and skills of an organization's employees have become increasingly important to their performance, competitiveness, and advancement. Thus, training to the employees of an organization plays a vital role to meet competition with better performance.

Training has traditionally been a conventional method utilized to prepare and arm both current and new employees with necessary and relevant knowledge and skills needed to perform day-today operational activities that ultimately determine organizational performance, success, and competitiveness (Sum, 2009). In modern days training is thought to be the catalyst of employees' performances in organization, especially when it is a service organization. The activities of training and development of employees are so closely related that it is difficult, and perhaps impossible, to make a clear distinction among them. Instead, the entire system of

Mohammad Rokibul Kabir, Assistant Professor, Department of Business Administration, International Islamic University Chittagong.

Md. Maruf Ullah, Lecturer, Department of Business Administration, International Islamic University Chittagong

Mustafa Manir Chowdhury, Assistant Professor, Department of Business Administration, International Islamic University Chittagong.

Correspondence concerning this article should be addressed to Mohammad Rokibul Kabir, Assistant Professor, Department of Business Administration, International Islamic University Chittagong, 154/A, College Road Chittagong-4203, Bangladesh. E-mail:rakibais@yahoo.com. 
activities usually is referred to simply as training and development. In general an organization's training and development practices are its intentional efforts to improve current and future performance by helping employees acquire the skills, knowledge, and attitudes required of a competitive workforce (Ndeleva, 2012). In earlier studies, researchers have found that HRM practices and training to the employees directly or indirectly affect other variables such as employee's attitude, employee employer relations, financial performance, employee productivity etc., and ultimately contribute to overall corporate performance (Tiwari \& Saxena, 2012).

As service organizations like banks are labour intensive, training to the employees of banks are important to study. Thus, this paper is an attempt to find the relationship between training to the employees of banks and impact of training on banks' performances, which is measured through profitability and productivity. To analyze such relationships training cost of 23 publicly traded commercial banks (out of 30), percentage of training cost to total operating expenses and their profit in 2011 have been taken and productivity growth during the period has been measured after collecting relevant data through questionnaire.

\section{Objectives of the Study}

The main purpose of the study is to find whether there is any relationship between training of employees with the performance of banks. Specifically it aims at:

- To find the impact of training on the productivity of the bank employees;

- To find whether there is any relationship between training cost and profitability of banks.

\section{Literature Review}

HRM (training and development) associated with higher work productivity, higher profits, and an increase innovation capacity. This suggests that the HRM can increase the ability of small companies to select, develop, and motivate a labour force capable to produce superior results (Grigor, 2008). It is significantly related to operational measures of performance, as well as operating expenses and pre-tax profits (Wright, Garden, \& Moynihan, 2003). Training has its main objective as improving performance in the near term and in a specific job by increasing employees' competencies. Most training for job knowledge and skills and require training before being placed in a job (Ndeleva, 2012).

Productivity helps firms, industries, and nations to achieve sustainable competitive advantage. Industry is a thrust area for countries in their quest for competitiveness. It must be noted that banks which have maintained the momentum of continuous growth, and profitability showed better ratio of manpower effectiveness. Each element has crucial sub-components which serve as building blocks for productivity (Disha, 2010).

Business owners understand the relationship between the success of their company and the productivity of their workers. When there is an increase in productivity, the company earns more. This is the primary reason why organizations take time to dwell on training sessions for their employees, to further productivity (Miller, 2008).

Sing and Mohanty (2012) stated that the risky businesses like credit banks which falls in the category of high profit high risk business, the training plays a small part in the productivity of the employees, i.e., the extent of relationship between these two is very low as compared to other basic manufacturing industries. Market forces like recovery of loans, liquidity available in the market, how prudently the customer of the services used the credit money play more crucial role in the productivity (Hoque et al., 2012). 
Bhattacharjee (1991) conducted a study titled An Evaluation of Performance of NCBs in 13 Bangladesh with a principle objective of evaluating the profitability performance of NCBs made by the measurement of performances of NCBs on the basis of five set of indicators, namely, general banking business including net profit, social profitability measures. The study revealed that almost all the performance measures showed upward trends. Of course, there were inter-bank and intra-bank variations in performance measures during the period, 1973 to 1987.

On the basis of above literature it can be seen that in previous studies productivity and training as well as productivity and profitability have been analyzed. But not much of previous study included the analysis of the relationship among all the three dimensions together. Thus, this study aims at finding the empirical relationship between training cost and productivity and profit.

\section{Theoretical Background}

Delivering satisfactory service to customers can help curb strong competition in the banking industry today. Clients do make great advertisers through word of mouth. Therefore, satisfying them is becomes a vital for any banking institution. When customers are entertained very well and their concerns are addressed properly, they will enjoy their banking experience with your financial institution. It will not take long for them to recommend your bank to one, two, or even a lot of their friends and colleagues. This will surely create a big impact on your earnings (Miller, 2008).Thus, a comprehensive training is essential to equip the employees with skill to achieve greater productivity and hence to contribute towards better earning. Hence, appropriate training design and relevant training cost analysis is a must which refers to the degree to which the training has been designed and delivered in such a way that provides trainees the ability to transfer learning back to the job. The author argues that part of transfer design is the degree to which training instructions match job requirements (Holton, 2000).

Productivity is defined as the goods and services produced per unit of labour, capital or both. The ratio of output to labour and capital is a total productivity measure. In simple words, productivity is the output per unit of input employed. The basic definition of productivity is:

$$
\text { Productivity }=\frac{\text { Total Output }}{\text { Total Input }}
$$

The concept of productivity analysis in banking sector may give misleading results, if not used carefully. The productivity measure related with training for banks can be done through the following productivity indicator.

\section{Productivity Related to Unsecured Loan}

Unsecured loan refers to the loan or general obligation that is not collateralized by a lien on specific assets of the borrower in the case of a bankruptcy or liquidation or failure to meet the terms for repayment (Wikipedia). It can be measured as:

$$
\begin{gathered}
\text { Productivity }(U S L)=\frac{\text { No. of Unsecurd Loan Processed in a Year }}{\text { No. of Month in a Year }} \\
\text { Productivity Growth }(U S L)=\frac{\text { Current Productivity }- \text { Previous Productivity }}{\text { Previous Productivity }}
\end{gathered}
$$




\section{Productivity Related to Secured Loan}

A secured loan is a loan in which the borrower pledges some asset as collateral for the loan, which then becomes a secured debt owed to the creditor who gives the loan. The debt is thus secured against the collateral —in the event that the borrower defaults, the creditor takes possession of the asset used as collateral and may sell it to regain some or the entire amount originally lent to the borrower (Wikipedia). It can be measured as:

$$
\begin{aligned}
\text { Productivity }(S L) & =\frac{\text { No. of Securd Loan Processed in a Year }}{\text { No. of Month in a Year }} \\
\text { Productivity Growth }(S L) & =\frac{\text { Current Productivity - Previous Productivity }}{\text { Previous Productivity }}
\end{aligned}
$$

\section{Productivity Related to Deposit Accounts Processing}

Money placed into a banking institution for safekeeping. Bank deposits are made to deposit accounts at a banking institution, such as current accounts, savings accounts. The account holder has the right to withdraw any deposited funds, as set forth in the terms and conditions of the account (investopedia). The "deposit" itself is a liability owed by the bank to the depositor (the person or entity that made the deposit), and refers to this liability rather than to the actual funds that are deposited. It can be measured as:

$$
\begin{aligned}
\text { Productivity }(D A P) & =\frac{\text { No. of Deposit Processed in a Year }}{\text { No. of Month in a Year }} \\
\text { Productivity Growth }(D A P) & =\frac{\text { Current Productivity - Previous Productivity }}{\text { Previous Productivity }}
\end{aligned}
$$

Profitability refers to profit earning capacity of an enterprise. It is one of the best measurements of evaluating of overall performance of an enterprise. In their research, Hoque et al. (2012) identified a positive relationship between productivity and profitability of Private Commercial Banks of Bangladesh.

Figure 1 shows how training costs can contribute to ensure better profitability through increasing productivity.

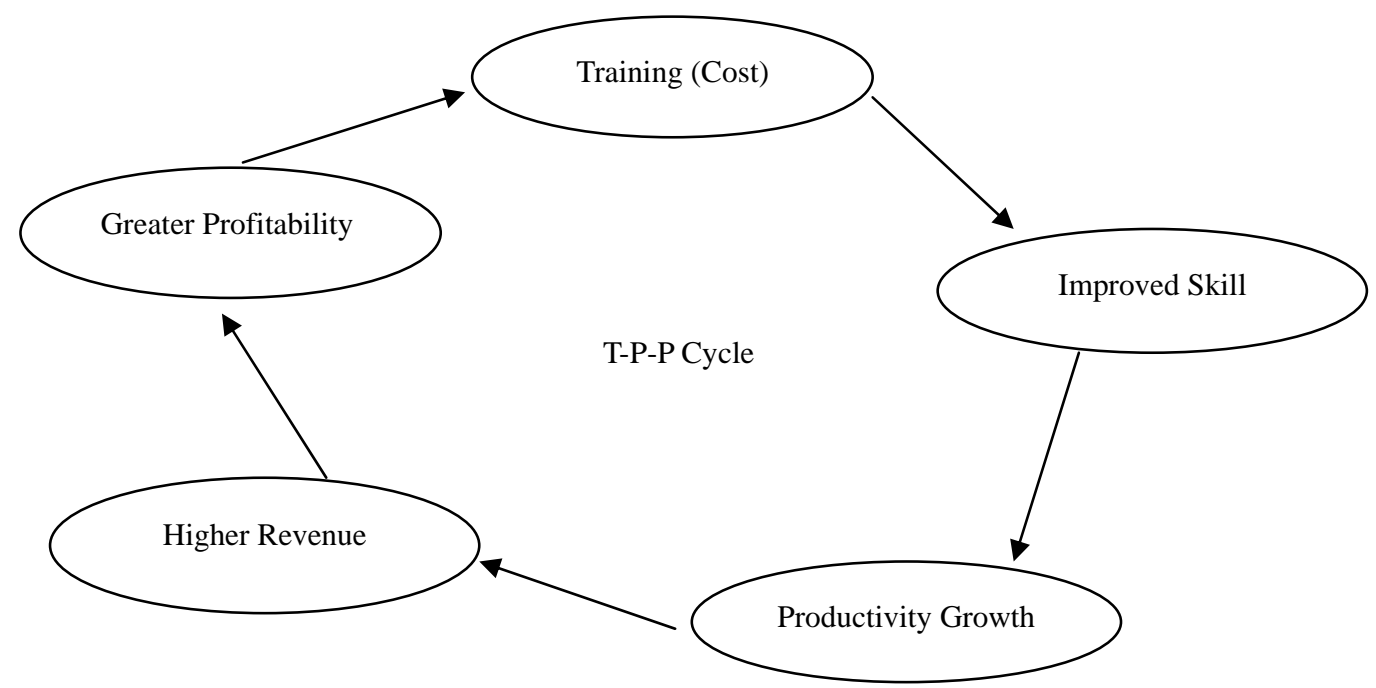

Figure 1. Training Productivity Profitability (TPP) cycle.

The Training Productivity Profitability (TPP) Cycle refers that investment in training (training cost) 
increases employees' skill that help improving productivity and brings higher revenue leading towards greater profitability.

\section{Methodology of the Study}

This paper is an endeavor to identify the impact of training on productivity and to what extend training cost can influence the profit growth. Thus, this study is conducted into two different segments. In the first segment, an attempt has been made to find the relationship between training and productivity, while in the second segment an effort has been initiated to establish a regression model between training cost and profit of banks.

\section{Sample Selection}

The study has been conducted considering the listed companies in Bangladesh as reliable data are easily available in this regard. At present, there are 30 listed commercial banks in Bangladesh (Security and Stock Exchange 2012) out of which 23 banks have been selected randomly as sample.

\section{Data Collection}

This study is based on both primary and secondary data. Primary data are collected on the basis of a structured questionnaire using direct interview method from the bank officials engaged in processing unsecured loan, secured loan, and deposit accounts for the purpose of finding the relationship between training and productivity. Secondary data are collected from the annual reports of the sample banks for establishing the regression model considering training cost as independent variable and profit as the dependent variables of different banks. Data are collected in a 12 months period starting from the November, 2011 to the October, 2012.

\section{Statistical Tools Applied}

Statistical tools for training and productivity:

Productivities of unsecured loan, secured loan and deposit accounts processing have been calculated by using the formula stated in the theoretical background section for each of the 23 sample banks both before and after training of a set of bank officials then productivity growth has been calculate. Finally, the calculated data are fed to the SPSS-20 Software for conducting paired sample $T$-test to find whether the change in the productivity after training is significant.

Statistical tools for training cost and net profit:

Training cost and profit for 2011 of the 23 sample banks have been taken from their respective annual reports and fed to the SPSS-20 software to fit the regression model as follows:

$$
N P=\alpha_{1}+\beta_{1} T C
$$

where:

$N P=$ Net profit;

$\alpha_{1}=$ the increase in net profit in absence of training cost as a factor;

$\beta_{1}=$ the change in net profit due to one unit change in training cost.

\section{Results and Discussions}

\section{Training and Productivity}

The results of Table 1 show that in all the cases the growth rate of productivity after training is positive 
showing a positive relationship between training and productivity. To see whether this relationship is significant $T$-test has been conducted as follows:

Table 1

Productivity Growth

\begin{tabular}{|c|c|c|c|c|c|c|c|c|c|}
\hline \multirow{3}{*}{ Name of banks } & \multicolumn{5}{|c|}{ Loan } & \multirow{3}{*}{ Growth } & \multicolumn{2}{|c|}{ Deposit } & \multirow{3}{*}{ Growth } \\
\hline & \multicolumn{2}{|c|}{ Unsecured } & \multirow[t]{2}{*}{ Growth } & \multicolumn{2}{|l|}{ Secured } & & & & \\
\hline & Before $T$ & After $T$ & & Before $T$ & After $T$ & & Before $T$ & After $T$ & \\
\hline $\mathrm{AB}$ & 10.00 & 16.00 & 60.00 & 6.50 & 11.50 & 76.92 & 280.00 & 530.00 & 89.29 \\
\hline ALARAFA & 9.00 & 17.00 & 88.89 & 6.80 & 10.50 & 54.41 & 240.00 & 380.00 & 58.33 \\
\hline B.ASIA & 9.80 & 16.33 & 66.63 & 5.44 & 8.17 & 50.13 & 245.00 & 490.00 & 100.00 \\
\hline BRAC & 12.00 & 15.00 & 25.00 & 6.66 & 7.50 & 12.59 & 250.00 & 510.00 & 104.00 \\
\hline CITY & 15.00 & 27.00 & 80.00 & 8.33 & 13.50 & 62.13 & 255.00 & 580.00 & 127.45 \\
\hline DBBL & 12.00 & 19.00 & 58.33 & 6.66 & 9.50 & 42.62 & 290.00 & 520.00 & 79.31 \\
\hline EBL & 18.00 & 32.00 & 77.78 & 9.99 & 16.00 & 60.13 & 245.00 & 570.00 & 132.65 \\
\hline EXIM & 9.00 & 14.00 & 55.56 & 5.00 & 7.00 & 40.11 & 199.00 & 300.00 & 50.75 \\
\hline FIRSTSECURITY & 11.00 & 19.00 & 72.73 & 6.11 & 9.50 & 55.58 & 220.00 & 470.00 & 113.64 \\
\hline IBBL & 16.00 & 27.00 & 68.75 & 8.88 & 13.50 & 52.00 & 200.00 & 415.00 & 107.50 \\
\hline JAMUNA & 9.50 & 15.00 & 57.89 & 5.27 & 7.50 & 42.22 & 200.00 & 425.00 & 112.50 \\
\hline IFIC & 13.00 & 17.00 & 30.77 & 7.22 & 8.50 & 17.79 & 245.00 & 445.00 & 81.63 \\
\hline M.TRUST & 8.00 & 18.00 & 125.00 & 4.44 & 9.00 & 102.67 & 240.00 & 415.00 & 72.92 \\
\hline MERCANTILE & 12.00 & 16.50 & 37.50 & 6.66 & 8.25 & 23.85 & 225.00 & 390.00 & 73.33 \\
\hline ONEBANK & 9.50 & 15.50 & 63.16 & 5.27 & 7.75 & 46.96 & 250.00 & 485.00 & 94.00 \\
\hline PREMIER & 7.80 & 9.00 & 15.38 & 4.33 & 4.50 & 3.93 & 240.00 & 300.00 & 25.00 \\
\hline PRIME & 10.00 & 18.00 & 80.00 & 5.55 & 9.00 & 62.13 & 285.00 & 560.00 & 96.49 \\
\hline SIBL & 8.00 & 9.80 & 22.50 & 4.44 & 4.90 & 10.34 & 235.00 & 360.00 & 53.19 \\
\hline SHAJALAL & 9.00 & 13.00 & 44.44 & 5.00 & 6.50 & 30.11 & 230.00 & 380.00 & 65.22 \\
\hline SOUTHEAST & 8.00 & 9.00 & 12.50 & 4.44 & 4.50 & 1.33 & 230.00 & 320.00 & 39.13 \\
\hline TRUST & 8.00 & 19.00 & 137.50 & 4.44 & 9.50 & 113.93 & 230.00 & 400.00 & 73.91 \\
\hline UCB & 16.00 & 32.00 & 100.00 & 8.88 & 16.00 & 80.15 & 220.00 & 480.00 & 118.18 \\
\hline UTTARA & 7.50 & 8.50 & 13.33 & 4.16 & 4.25 & 2.08 & 200.00 & 220.00 & 10.00 \\
\hline
\end{tabular}

Table 2

Paired Sample T-test

\begin{tabular}{|c|c|c|c|c|c|c|c|c|c|}
\hline & & \multicolumn{5}{|c|}{ Paired differences } & \multirow{3}{*}{$t$} & \multirow{3}{*}{$d f$} & \multirow{3}{*}{$\begin{array}{l}\text { Sig. } \\
\text { (2-tailed) }\end{array}$} \\
\hline & & \multirow[t]{2}{*}{ Mean } & \multirow{2}{*}{$\begin{array}{l}\text { Std. } \\
\text { deviation }\end{array}$} & \multirow{2}{*}{$\begin{array}{l}\text { Std. error } \\
\text { mean }\end{array}$} & \multicolumn{2}{|c|}{$\begin{array}{l}\text { 95\% confidence interval of the } \\
\text { difference }\end{array}$} & & & \\
\hline & & & & & Lower & Upper & & & \\
\hline Pair 1 & $\begin{array}{l}\text { PULBT } \\
\text { PULAT }\end{array}$ & -6.71870 & 4.14828 & 0.86498 & -8.51255 & -4.92485 & -7.767 & 22 & 0.000 \\
\hline Pair 2 & $\begin{array}{l}\text { PSLBT } \\
\text { PSLAT }\end{array}$ & -2.88478 & 2.02238 & 0.42170 & -3.75932 & -2.01024 & -6.841 & 22 & 0.000 \\
\hline Pair 3 & $\begin{array}{l}\text { PDBT } \\
\text { PDAT }\end{array}$ & -195.26087 & 80.32164 & 16.74822 & -229.99455 & -160.52719 & -11.659 & 22 & 0.000 \\
\hline
\end{tabular}

Paired sample $T$-test has been applied to find whether the change in productivity before and after training is significant. The first pair of Table 2 consists of Productivity of Unsecured loan Before Training (PULBT) and Productivity of Unsecured loan After Training (PULAT). The results show that the change in productivity is significant at $1 \%$ significant level. The second pair of Table 2 consists of Productivity of Secured loan Before 
Training (PSLBT) and Productivity of Secured loan After Training (PSLAT). The results also show that the change in productivity is significant at $1 \%$ significant level. Finally, the pair related to Deposits Productivity of Deposits Account Processing Before Training (PDBT) and Productivity of Deposits Account Processing After Training (PDBT) indicate a significant Change at $1 \%$ significant level which can be seen in Table 2.

\section{Training Cost and Profitability}

Table 3

Model Summary

\begin{tabular}{lllll}
\hline Model & $R$ & $R$ square & Adjusted $R$ square & Std. error of the estimate \\
\hline 1 & $0.673^{\text {a }}$ & 0.453 & 0.427 & $754,335,833.64435$ \\
\hline Note. $^{\text {a }}$ : Predictors: (Constant), Training cost. & &
\end{tabular}

Table 4

ANOVA $^{\text {a }}$

\begin{tabular}{llcrrll}
\hline Model & & Sum of Squares & $d f$ & Mean square & $F$ & Sig. \\
\hline \multirow{3}{*}{1} & Regression & $9,905 \mathrm{E}+18$ & 1 & $9,905 \mathrm{E}+18$ & 17.407 & $0.000 \mathrm{~b}$ \\
& Residual & $1.195 \mathrm{E}+19$ & 21 & $1.195 \mathrm{E}+19$ & & \\
\cline { 2 - 7 } & Total & $2.185+\mathrm{E} 19$ & 22 & & & \\
\hline
\end{tabular}

Note. ${ }^{a}$ : Dependent Variable: NOI; b: Predictors: (Constant), Training cost.

From the Table 4 we can see that the $F$-statistics for this study is significant at 1 percent level (Sig. $F<$ 0.1 ), showing the fitness of the model. For the coefficient of determination, Adjusted $R^{2}$ (in Table 3) stated 0.427 , indicating that $42.7 \%$ of the changes in the net profit can be explained by the changes in the independent variable training cost.

Table 5

Coefficients $^{a}$

\begin{tabular}{|c|c|c|c|c|c|c|}
\hline \multirow{2}{*}{ Model } & & \multicolumn{2}{|c|}{ Unstandardized coefficients } & \multirow{2}{*}{$\begin{array}{l}\text { Standardized } \\
\text { coefficients } \\
\text { Beta } \\
\end{array}$} & \multirow[t]{2}{*}{$t$} & \multirow{2}{*}{ Sig. } \\
\hline & & $\mathrm{B}$ & Std. error & & & \\
\hline \multirow{2}{*}{1} & (Constant) & $1,115,384,804.187$ & $226,853,558.813$ & & 4.917 & 0.000 \\
\hline & Training cost & 69.511 & 16.661 & 0.673 & 4.172 & 0.000 \\
\hline
\end{tabular}

Note. ${ }^{a}$ : Dependent variable: NOI.

The fitted regression model on the basis of the results of Table 5 can be expressed as:

$$
N P=1,115,384,804.187+69.511 T C
$$

The above function indicates that a one taka increase in training cost will result in a Tk.69.511 increase in net profit taking other things constant.

\section{Practical Implications for Business}

The results of the study show that training and productivity are positively and significantly related. Similarly, training cost has a significant impact on the profit earning capability of banks. Thus, the bank authorities should take necessary steps to design their training program after training need assessment so that the employees of the bank can enhance their productivity which in turn will ensure better earning capability.

\section{Scope for Future Research}

The study is conducted to find the relationship between training and productivity, but it did not take under 
consideration of the effect of other factors of productivity like financial and nonfinancial motivations, learning curve, age, experience and so on. Again, training cost is considered as the only independent variable to find its effect on profit of banks. If other variables like size of banks, branch locations, and such other things were considered there might be an effect on the results. Hence, an extensive and comprehensive study can be initiated taking all the above mentioned factors.

\section{Conclusions}

This study successfully explored the relationship between training cost and productivity as well as the impact of training cost on profit earning capability of banks. Thus, this research has provided valuable knowledge and information to banking authorities about the importance of training in increasing productivity and hence the profitability of banks. Consequently, it can be concluded that the banks which will train their employees in a proper way stand to gain considerable improvement in productivity and to serve more number of clients with satisfaction.

\section{References}

Bhattacharjee, D. (1991). Productivity measurement in the nationalized commercial banks of Bangladesh: A multivariate analysis. The Dhaka University Studies, XII(1), 25-43.

Disha, B. (2010). Impact of liberalisation on productivity and profitability of public sector banks in India (Ph.D. thesis, Edith Saurashtra University).

Grigore, A. M. (2008). The impact of human resources practices upon small companies performances. BULETINULUniversității Petrol-Gaze din Ploieşti, LX(2), 83-92.

Holton, E. F. (2000). Large-scale performance-driven training needs assessment. Public Personnel Management, 29(2), $249-267$.

Hoque et. al. (2012). Impact of training practices on employee productivity: A comparative study. Retrieved from http://www.wbiconpro.com/621-Johirul.pdf

Miller, S. (2008). Banking training boosts employees' productivity. Retrieved September 12, 2012, from http://EzineArticles.com/1148796

Ndeleva, M. (2012). Training and staff productivity. Retrieved September 10, 2012, from http://www.studymode.com/essays/Training-And-Staff-Productivity-1064430.html

Sing, R., \& Mohanty, M. (2012). Impact of training practices on employee productivity: A comparative study. Interscience Management Review (IMR), 2(2), 74.

Sum, V. (2009). Integrating training in business strategies means greater impact of training on the firm's competitiveness (Ph.D. thesis, Southern Illinois University Carbondale). Retrieved from http://opensiuc.lib.siu.edu/dissertations/82 or http://www.vichetsum.com/viewcontent.pdf

Tiwari, P. J., \& Saxena, K. (2012). Human resource management practices: A comprehensive review. Pakistan Business Review, 9(2), 669-705

Wright, P. M., Garden, T. M., \& Moynihan, L. M. (2003). The impact of HR practices on the performance of business units. Human Resource Management Journal, 13(3), 21-36. 